Boston University School of Law

Scholarly Commons at Boston University School of Law

Faculty Scholarship

7-2016

\title{
Reflections of an Empirical Reader (Or: Could Fleming Be Right This Time?)
}

Gary S. Lawson

Boston Univeristy School of Law

Follow this and additional works at: https://scholarship.law.bu.edu/faculty_scholarship

Part of the Constitutional Law Commons

\section{Recommended Citation}

Gary S. Lawson, Reflections of an Empirical Reader (Or: Could Fleming Be Right This Time?), in 96 Boston University Law Review 1457 (2016).

Available at: https://scholarship.law.bu.edu/faculty_scholarship/801

This Article is brought to you for free and open access by Scholarly Commons at Boston University School of Law. It has been accepted for inclusion in Faculty Scholarship by an authorized administrator of Scholarly Commons at Boston University School of Law. For more information, please contact lawlessa@bu.edu. 


\title{
REFLECTIONS OF AN EMPIRICAL READER (OR: COULD FLEMING BE RIGHT THIS TIME?)*
}

\author{
GARY LAWSON ${ }^{\dagger}$
}

I. The LeAST DANGERous BRANCH (OF PHILOSOPHY) ..........................1459

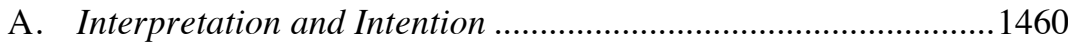

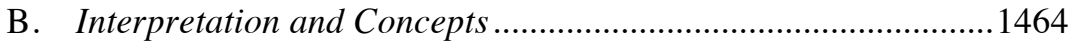

II. What Is OLD ABOUT THE OLD ORIGINALISM AND NEW ABOUT

THE NEW ORIGINALISM (AND NEW NEW ABOUT THE NEW NEW

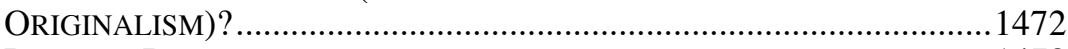

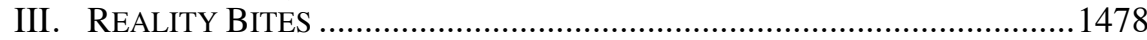

Jim Fleming's new book, Fidelity to Our Imperfect Constitution: For Moral Readings and Against Originalisms, purports to critique all forms of originalism from the perspective of Fleming's "moral reading" of, or "philosophic approach" to interpreting, the Constitution. I propose a somewhat different opposition: empirical reading versus moral reading. Empirical reading is necessarily originalist, but it focuses directly on the need to ground interpretation in theories of concepts, language, and communication. In this short comment, I outline the research agenda for a theory of empirical reading, explore the extent to which empirical readings and moral readings of the Constitution are compatible (spoiler alert: it's an empirical question), and situate empirical reading within the development of originalist theory.

Jim Fleming's characteristically intriguing new book, Fidelity to Our Imperfect Constitution: For Moral Readings and Against Originalisms, ${ }^{1}$ purports to set up an opposition between originalism(s) and what Fleming calls a "moral reading" of, or "philosophic approach" to interpreting, the Constitution. ${ }^{2}$ By a "moral reading" or "philosophic approach," he means reference to "conceptions of the Constitution as embodying abstract moral and political principles - not codifying concrete historical rules or practices-and of interpretation of those principles as requiring normative judgments about how they are best understood-not merely historical research to discover

\footnotetext{
* With apologies to Sandy Levinson.

$\dagger$ Philip S. Beck Professor of Law, Boston University School of Law.

${ }^{1}$ James E. Fleming, Fidelity to Our Imperfect Constitution: For Moral Readings AND AGAinst ORIGINALISMS (2015).

${ }^{2} I d$. at 3 .
} 
relatively specific original meanings." ${ }^{3} \mathrm{He}$ offers this view as an alternative most directly to "[c]onventional, strong" prescribe that " $[\mathrm{t}]$ he only legitimate source of constitutional interpretation is the relatively specific original meanings and original expected applications of the founders." 5 The bane of his existence is what he calls "the originalist premise," which is

the assumption that originalism, rightly conceived, has to be the best-or indeed the only-conception of constitutional interpretation. Why so? Because originalism, rightly conceived, just has to be. By definition. In the nature of things - in the nature of the Constitution, in the nature of law, in the nature of interpretation, in the nature of fidelity in constitutional interpretation. Axiomatically. ${ }^{6}$

He styles the book "a sustained critique of originalism - whether old or new, concrete or abstract, living or dead."7

Fleming is right that the term "originalism" now describes so many different approaches that the label may obscure more than it conveys. ${ }^{8}$ I certainly do not want to be in the position of denying the label "originalist" to anyone who wants to claim it, but when I am supposedly standing shoulder to shoulder as an "originalist" with, inter alia, Bruce Ackerman, Larry Alexander, Sam Alito, Akhil Amar, Jack Balkin, Randy Barnett, Will Baude, Raoul Berger, and Robert Bork-and those are just the "As" and "Bs" that leap immediately to mind who are swept in by some currently circulating broad definitions of originalism-it is not clear that the label "originalist" is doing a lot of useful epistemological work. Accordingly, although I consider myself an originalist of sorts, rather than defend originalism here, I instead propose a somewhat different opposition in response to Fleming: empirical readings versus moral readings. Framing the issue this way reveals some very strange bedfellows and points to what I believe is a radically underdeveloped research agenda for constitutional interpretation.

By "empirical reading," I mean nothing more complex than reading the Constitution-or any communicative instrument, such as the Gettysburg Address, the Constitution of the Confederate States of America, your spouse's shopping list, or Fleming's book - for what it says. That is an empirical task because communicative meaning in a wide range of contexts is a fact to be

\footnotetext{
${ }^{3} I d$.

${ }^{4} I d$. at 1.

${ }^{5} I d$.

${ }^{6} I d$. at 7.

${ }^{7} \mathrm{Id}$. at xi.

${ }^{8} I d$. at 2-3 (chronicling the varieties of originalism and cautioning that "if we define originalism so inclusively - and we are all now in this big tent-we may obscure our differences more than elucidate common ground"). As Fleming recognizes, he is far from alone in this observation about originalism's "balkanization." See, e.g., Mitchell N. Berman, Originalism Is Bunk, 84 N.Y.U. L. REV. 1, 16-17 (2009).
} 
discovered rather than something to be constructed, invented, or chosen. To discover the factual meaning of the United States Constitution, one must ascertain the original intentions of the document's author. That is the right way to discover meaning in that context. It just has to be.

So stated, this position seems to represent precisely the kind of dogmatically axiomatic, concrete-intentions-based, authoritarian originalism that Fidelity to Our Imperfect Constitution wants to stamp out. Not so fast. There is both more and less to empirical reading than meets the eye.

The subtitle of this Comment is "Could Fleming Be Right This Time?" The answer to that question is yes, and even obviously yes. But, as with "[f]ortytwo" as the answer to the ultimate question of life, the universe, and everything, ${ }^{9}$ the trick is to formulate the question properly. What, exactly, is the ultimate question of meaning, interpretation, and the Constitution to which Fleming has given the right answer? My goals in this brief Comment are to explain the relationship between empirical readings and moral readings of the Constitution and to identify precisely what, from the standpoint of an empirical reader, Fleming has right this time. The short answer-which, out of full context, is about as helpful as "forty-two"-is that Fleming is right that constitutional interpretation requires a philosophic approach; that the old and the new new (though not necessarily the new) originalisms often amount to thinly veiled moral readings; and that originalism, even when properly conceived as empirical reading, is authoritarian. He is wrong about what kind of philosophy one needs for interpretation; wrong that all originalisms, including empirical readings, fall prey to his critique; and wrong about the kind of authoritarianism that originalism, when cast as empirical reading, represents.

In order to determine what is right and wrong about Fleming's account, one must think deeply and carefully about the nature of interpretation. Since the value of scholarship, in my eyes, is measured by how well it prompts deep and careful thought, I am profoundly grateful to Fleming, as we all should be, for his immensely valuable work.

\section{The Least Dangerous BRANCH (OF PhILOSOPHY)}

Notwithstanding Fleming's protestations, some form of originalism just has to be the right method for ascertaining the meaning of the Constitution. It just has to be. This is not an axiomatic assertion. It is a demonstrable truth.

When faced with a document, one can do any number of things with it. One can read it for aesthetic pleasure. One can use it as a coaster for a cup of tea. One can treat it as a blueprint for social organization (remember "A Piece of the Action" from the original Star Trek series, in which a book on 1920s Chicago gangs became the foundation for an entire alien culture). ${ }^{10}$ One can try

\footnotetext{
9 Douglas Adams, The HitchHiKeR's Guide to the Galaxy 135 (1979).

${ }^{10}$ Star Trek: The Original Series: A Piece of the Action (NBC television broadcast Jan. $12,1968)$.
} 
to dupe low-information or weak-minded people into treating one's propounded version of it as a blueprint for social organization so that one can more readily impose one's values on them and steal their wealth. Or one can try to figure out what it actually says. Of course, in doing any of those other activities, one might also try to figure out what it actually says, but one can perform any of those other activities without trying to figure out what it actually says. And one can try to figure out what it actually says without performing any of those other activities. The latter proposition tends to get obscured in the context of the United States Constitution because, as a matter of practice, interpretation of the document is almost always bound up with decisions that implicate the real-world employment of government force. But, conceptually, the meaning of the document and the consequences, if any, of that meaning are quite different things. To keep those very different ideas clear, just imagine that we are interpreting the Constitution of the Confederate States of America or an old Soviet constitution, so that ascertainment of meaning does not have any current political implications and one's judgment will therefore not be distorted by hopes or wishes about how that meaning will affect people's behavior.

If one genuinely and honestly tries to figure out what the document actually says, then, as a hypothetical imperative, one must be an empirical reader, which means in turn that one must be an originalist. One simply has to be. The conclusions follow from the nature of the Constitution as a communicative instrument and the nature of language as a tool for communication.

\section{A. Interpretation and Intention}

Most documents are human acts of communication. It is possible, to be sure, to imagine a document that has no communicative content, either because it is simply random marks or because it is designed to produce emotive rather than cognitive content. Most of the time, however, documents are constructed in order to convey information-about entities, commands, reactions, or any other aspect of the physical, mental, or moral world-from one mind to another, even if the respective minds belong to the same person at different points in time. Once one identifies a document as an attempt to communicate cognitive content, it follows ineluctably that the meaning of the document is the content that was intended to be communicated. If you are not trying to figure out what the author of a communication intended to communicate, you are not engaged in the enterprise of communication. Of course, your efforts to figure out communicative content may fail because you do a bad job of understanding (either on purpose or through lack of skill or attention), the communicator does a bad job of communicating (either on purpose or through lack of skill or attention), the subject matter of the communication is difficult to convey from mind to mind despite everyone's best efforts, or any or all of the above. To say that interpretation is about communication is not to say that interpretation will always yield an answer that can epistemologically be 
proclaimed correct. ${ }^{11}$ But if you are not even trying to ascertain the content of a communication, you are not participating in an activity that can meaningfully be called communication. You may be engaged in some other activity (such as imposing values or stealing wealth), and that other activity may be very important, and perhaps even more important than the communicative enterprise, but it is not communication. I use the word "interpretation" to describe the process of ascertaining the meaning of, and therefore the intentions behind, a communicative act. ${ }^{12}$ Thus, interpretation "just is" the ascertainment of the original intentions of the communicator. When people like Cass Sunstein say that "no approach to interpretation is dictated by the very idea of interpretation," 13 they are simply wrong.

But couldn't one use the word "interpretation" to describe some cognitive activity other than the ascertainment of meaning, such as figuring out the morally best account of communicative marks that somehow stays within certain conventional linguistic parameters? Of course one could. ${ }^{14}$ Just like in the old joke about baptism, I've seen it. Indeed, I have elsewhere identified at least eight functions that Jack Balkin believes constitutional "interpretation" should try to perform, ${ }^{15}$ and Jack Balkin is a skilled user of the English

11 The degree to which attempts to understand communication will yield correct answers depends on a wide range of considerations, including the standard of proof that governs the communicative enterprise and the evidence set that is applied to the task. See generally Gary Lawson, Evidence of the Law: Proving Legal Claims (forthcoming 2017).

12 This is not an idiosyncratic usage of the term "interpretation." See, e.g., Lawrence B. Solum, Intellectual History as Constitutional Theory, 101 VA. L. REV. 1111, 1119 (2015) ("I shall use the word 'interpretation' to refer to the activity of discovering the communicative content of the constitutional text.").

13 Cass R. Sunstein, Second-Order Perfectionism, 75 Fordham L. REV. 2867, 2874 (2007) [hereinafter Sunstein, Second-Order Perfectionism]. For a recent (though equally mistaken) elaboration of Professor Sunstein's position, see Cass R. Sunstein, There Is Nothing that Interpretation Just Is, 30 CONST. CoMmENT. 193, 193 (2015) [hereinafter Sunstein, There Is Nothing That Interpretation Just Is].

${ }^{14}$ Similarly, there are any number of ways in which one can use the word "meaning." See Richard H. Fallon Jr., The Meaning of Legal "Meaning" and Its Implications for Theories of Legal Interpretation, 82 U. CHI. L. REV. 1235, 1246-62 (2015); Solum, supra note 12 , at 1116 (discussing different ways of using the term "meaning").

15 Gary Lawson, Dead Document Walking, 92 B.U. L. REV. 1225, 1227-28 (2012) (suggesting that Balkin wants a theory of constitutional interpretation to serve the following eight functions: "[T]o (1) ascertain the semantic meaning of constitutional language, (2) construct meaning when the ascertainment of semantic meaning is not possible, (3) be adequate to our history as a people by explaining and accounting for constitutional developments widely regarded as good, (4) explain the process of constitutional change by (among other things) accounting for how political and social movements and postenactment history shape our constitutional traditions, (5) allow for viable critiques of existing practices in the name of a deeper constitutional fidelity, (6) provide a vehicle for popular discourse about political and social change, (7) connect the present and past in a fashion that promotes identification between ourselves, those who lived in the past, and 
language. One can use a word to mean anything that one likes as long as the usage is clearly defined - so that readers and listeners will be able to ascertain the original intentions of, and therefore the communicative content conveyed by, the user of the word. One can even use the word "interpretation" to describe the process of projecting future events from an examination of goat entrails or the process of predicting personality traits from arrangements of stars, and as long as the term's usage is clearly defined, effective communication can take place. But in any activity other than discerning the original intentions of a communicator, one is not ascertaining meaning. One is not discovering the content conveyed by an utterance that exists independently of the conscious mind of the specific perceiver. That ascertainment of meaning is the aspect of reality that I mean as the referent for the term "interpretation." If other people want to use the word "interpretation" to describe different aspects of reality-such as moral readings, Balkin's eight tasks, or the examination of goat entrails - that is certainly their right, and I could hardly deny them use of the word for that purpose. I would say only that if one uses the word "interpretation" to mean something other than the ascertainment of meaning, one must be careful to avoid the fallacy of equivocation by switching meanings mid-argument or by trying to cash in on implications or assumptions that accompany interpretation-as-ascertainment-of-meaning. By the same token, those of us who use the word "interpretation" to signify the ascertainment of meaning must similarly avoid switching meanings midstream or appealing to implications that accompany other meanings. Where there is a risk that people are using the same word to describe very different aspects of reality, clarity demands that people spell out their word usages with some care. Of course, if one's goal is to take advantage of the possibility of equivocation in order to help make the weaker argument defeat the stronger, hiding your meaning or bait-and-switch may be attractive options.

I am not interested in who gets custody of the word "interpretation." I am interested in the underlying, objectively existing phenomenon that I am using the word to describe: the activity of ascertaining communicative meaning. Empirical reading involves the ascertainment of that meaning. And ascertainment of that meaning requires ascertainment of the communicative intentions behind the utterance whose meaning is being ascertained.

Thus, this account of interpretation-as-ascertainment-of-meaning involves, not an axiomatic assertion of linguistic necessity, but a hypothetical imperative: if one wants to understand a communication, then one must employ a methodology of original intentions in order to achieve that goal. ${ }^{16}$

those who will live in the future, and (8) promote the democratic legitimacy of a constitutional and legal system that is based on the idea of popular sovereignty, which requires attention to sociological, procedural, and moral aspects of legitimacy.").

${ }^{16}$ Sunstein, perhaps unintentionally, makes the same point. See Sunstein, Second-Order Perfectionism, supra note 13, at 2871 ("We ask about the speaker's intentions because, and to the extent that, the goal of communication will go badly, or at least less well, if we do 
Whether one ought, in any particular instance, to want to understand a communication is a question of moral theory rather than interpretative or legal theory, and I therefore have nothing useful or interesting to say about it in an academic forum.

So, if one is an empirical reader attempting to ascertain meaning, does that establish that one, therefore, cannot be a moral reader who looks to "conceptions of the Constitution as embodying abstract moral and political principles-not codifying concrete historical rules or practices-and of interpretation of those principles as requiring normative judgments about how they are best understood - not merely historical research to discover relatively specific original meanings"? ${ }^{17} \mathrm{No}$, it does not necessarily establish anything of the kind. From the standpoint of interpretative theory, the extent to which an empirical reader will also be a moral reader is an empirical question.

Empirical reading says to look for the intentions of the Constitution's author. It prejudges nothing about the content of those intentions. Perhaps those intentions will take the form of relatively specific commands and instantiations that require little or nothing by way of moral judgment, but that is hardly foreordained. If the Constitution contained a provision that said, "Interpret everything in this document to approximate as closely as linguistically possible your understanding of the best moral theory at the moment of interpretation," a good empirical reader would have to be a Flemingian (Flemingal? Flemish?) moral reader, because the clearly expressed empirical intention of that provision is to prescribe a moral reading. The Constitution, of course, contains no such clause. But neither does it contain a clause that says, "Interpret everything in this document in accordance with the concrete and specific expected applications of the author." In order to determine how specifically or abstractly to interpret the Constitution and the extent to which it calls for a "moral reading," either in general or in particular instances, one must look at it.

A good many self-described originalists do not actually look at the Constitution in this fashion, at least not carefully enough to ascertain the appropriate role, if any, for a moral reading. For example, Justice Scalia generally insisted that constitutional provisions be read, to the extent possible, in a strictly rule-like fashion. ${ }^{18}$ But this interpretative move is not derived from

not.”). Professor Sunstein makes this statement in the context of rejecting the idea that interpretation just is the ascertainment of communicative intentions. See id. at 2870-72. He is right, as I have already noted, that one can attach the word "interpretation" to all sorts of activities that have nothing to do with ascertaining communicative intentions. See Sunstein, There Is Nothing That Interpretation Just Is, supra note 13, at 198-200. I am talking about the activity of ascertaining communicative meaning, not the particular psycho-linguistic symbol used to describe it.

17 FLEMING, supra note 1, at 3.

18 See Antonin Scalia, The Rule of Law as a Law of Rules, 56 U. CHI. L. REV. 1175, 1187 (1989) ("All I urge is that . . . [discretion-based] modes of analysis be avoided where possible; that the Rule of Law, the law of rules, be extended as far as the nature of the 
interpretation. It comes instead from a normative theory of law combined with a normative vision of the role of judges. If the Constitution, read empirically, actually prescribed those normative theories as tools for the ascertainment of meaning, Justice Scalia would be right as an interpretative matter. As Steve Calabresi and I have tried to show, however, that is not actually a correct empirical reading of the Constitution. Some provisions are best read as rules while others are best read as standards calling for the exercise of considerable degrees of judgment, and there are actually more of the latter than might appear at first glance. ${ }^{19}$ In order to discover how to interpret a particular provision, there is no good substitute for reading it. On that point, Fleming is absolutely right.

I think he is not quite as right, however, about either the mechanics or the results of that discovery process. To explore the subject, however, requires several long detours. And by "long" I mean "book-length." A full response to Fleming requires execution of a research program for originalist interpretation that is currently in its infancy. One needs to explore the theory of communication to understand the relationship between authors and readers, one needs to explore the theory of language to understand how communication functions when accomplished through language, and one needs to elaborate a theory of concepts to make the theories of communication and language robust and accurate. In my short space here, I mean (intend) only to outline the vaguest sketch of that research program as a guide to future work.

\section{B. Interpretation and Concepts}

Once one identifies ascertainment of meaning of a communicative utterance as a goal, the right tools for that task must come from a study of the nature of communication. ${ }^{20}$ When that communication is through language, the right tools for that task must include the philosophy of language. A sound approach to the philosophy of language, in turn, must be grounded in a sound approach to the theory of concepts, because language is a tool by which concepts are given a perceptual form and thereby made more accessible to the mind. Once that epistemological and linguistic foundation is laid, one must then return to communication theory to explore the respective roles of authors and interpreters in the communicative enterprise. Any account of interpretation that

question allows; and that, to foster a correct attitude toward the matter, we appellate judges bear in mind that when we have finally reached the point where we can do no more than consult the totality of the circumstances, we are acting more as fact-finders than as expositors of the law.").

${ }^{19}$ Steven G. Calabresi \& Gary Lawson, The Rule of Law as a Law of Law, 90 NOTRE DAME L. REV. 483, 502 (2014).

20 See Corey Rayburn Yung, Constitutional Communication, 96 B.U. L. Rev. 303, 30911 (2016) (critiquing extant theories of constitutional interpretation for failing to distinguish between language and communication as distinct, and asserting that one must focus on the nature of communication in constitutional interpretation). 
does not engage these issues is, to put it unkindly, simply hot gas (or, more likely, is using the word "interpretation" to refer to something other than the ascertainment of meaning).

As I have said, to engage any of these issues, much less all of them, is a book-length project at the very least. I hope to embark on that project in the (given my other commitments) relatively distant future. For present purposes, I will have to make do with the following brief, and tentative, observations that lay out the research agenda for an account of empirical reading.

First, the philosophy of language is a hotly contested field. ${ }^{21}$ That is largely, I believe, because it is insufficiently connected to an underlying theory of concepts. Because the theory of concepts is also hotly contested, it is understandable why someone toiling in the philosophy of language would hope to avoid that thicket. I doubt, however, whether such avoidance is possible.

Second, communication is sometimes divided into semantics and pragmatics, with the latter including aspects of communication that go beyond sentence meanings that can be derived from standard uses of words. ${ }^{22}$ If one is not looking at pragmatics, however, it is hard for me to see how one can be engaged in the enterprise of communication. If communication has a pragmatic component, one is not communicating if one ignores that component. It would be like tracking three-dimensional motion without one of the vectors. Accordingly, I use "communication," "meaning," "interpretation," and all related terms to include the pragmatic component of the communicative enterprise.

Third, there is a potentially complex relationship between authorial intentions and reader, or public reader, understandings that is directly relevant to constitutional interpretation. As Jeff Powell pointed out decades ago, a focus on authorial intentions does not necessarily require, at least as an operational matter, that one try to discern the subjective intentions of the relevant author. ${ }^{23}$ It might very well be that an author's intention is to put out into the world utterances that will then be given meanings by a group of readers (which may well require constructing a hypothetical single reader who does not correspond to any particular concrete person), in which case the authorial intention reduces in practice to a kind of public meaning. But that operational use of public meaning is a second-order move, derived from the first-order ascertainment of

${ }^{21}$ Consider, for example, the various essays compiled by Andrei Marmor and Scott Soames. See generally Philosophical Foundations of LANGUAGE IN THE LAW (Andrei Marmor \& Scott Soames eds., 2011). As a general introduction to the relevance of philosophy of language to legal theory, one could do much worse than to consult ANDREI MARMOR, THE LANGUAGE OF LAW (2014). I mean by this no slight to other philosophers of language who regularly address legal issues (Larry Alexander, Mark Greenberg, John Perry, Scott Soames, and Larry Solum leap immediately to mind); when I get to the full treatment of the subject in a book, they will all get their due.

${ }^{22}$ See MARMOR, supra note 21, at 5-6.

${ }^{23}$ H. Jefferson Powell, The Original Understanding of Original Intent, 98 HARV. L. REV. 885, 938-39 (1985). 
authorial intention to have a public understanding serve as the effective locus of meaning.

Larry Solum has recently put this point very elegantly:

[W] hat is sometimes called "public meaning originalism" is actually consistent with and a consequence of what is called "original intentions originalism"-except in the rare case where the author is crazy or for some other reason is radically mistaken about the linguistic beliefs and competences of the intended audience. This becomes apparent once we see that the relevant intentions are communicative intentions directed to the public. The Framers' meaning of the constitutional text is the meaning the Framers intended the public to grasp on the basis of the public's recognition of the Framers' communicative intentions: That meaning is necessarily public meaning. For this reason, the structure of communicative intentions (the object of original intentions originalism) necessarily focuses on public meaning (the object of public meaning originalism) as the means by which communication occurs. ${ }^{24}$

Throughout, the theoretical foundation of meaning remains authorial, or communicative, intention, but the practical thrust of interpretation will often be directed by that theoretical foundation to the understandings of interpreters. The extent to which one might expect authorial intention to amount in practice to public meaning depends on the kind of document involved. Private diaries, for example, are unlikely to embody that kind of meaning-from-publicunderstanding intention. Legal documents are more likely to embody such an externally directed intention, since legal documents contemplate, and indeed require, the active involvement of third parties for their effectiveness.

Fourth, the "author" of the Constitution whose intentions foundationally determine the document's meaning is not any particular historical Framer or group of Framers. It is not even a real person. The author of the Constitution, as identified by the Constitution itself, is "We the People," 25 which is a hypothetical, legally constructed entity. ${ }^{26}$ The public audience to which "We the People's" communication is addressed and whose understanding constitutes the operational meaning of a communicative instrument such as the Constitution is, in turn, also a hypothetical construction, because "the public" cannot mean, intend, or understand anything. Only an actual mind, whether real or hypothetical, can perform those acts. Just as joint authorship gives rise

\footnotetext{
${ }^{24}$ Solum, supra note 12, at 1136 (footnotes omitted). I would add to Solum's incisive analysis the observation that this account of authorial intentions assumes a good-faith desire to communicate information rather than a plan to confuse or deceive. See Andrei Marmor, Can the Law Imply More than It Says? On Some Pragmatic Aspects of Strategic Speech, in Philosophical Foundations of LANGUAGE In THE LAW, supra note 21, at 93-95.

25 See U.S. CONST. pmbl.

${ }^{26}$ For more on "We the People" as the Constitution's legal author, and on the metaphysics of joint intentions, see Gary Lawson \& Guy Seidman, Originalism as a Legal Enterprise, 23 CONST. COMMENT. 47, 59 (2006).
} 
to a single hypothetical author, joint readership gives rise to a single hypothetical reader, at least in any context in which the evident authorial intention is to convey a single meaning. ${ }^{27}$

Fifth, and finally, none of the foregoing observations can really provide clear insight into meaning until it is joined to a theory of concepts. At this juncture, one must be very careful to keep clear the Dworkinian distinction, adopted by Fleming, between concepts and conceptions. ${ }^{28}$ This distinction is absolutely crucial to sound interpretation, but not quite in the way that Dworkin (or, I believe, Fleming) presents it.

Concepts are cognitive tools designed to organize a complex reality.$^{29}$ They are integrations of units - aspects of the physical, mental, moral, or relational

27 There are surely contexts in which authors intend for meanings to vary with the reader. Legal documents are especially unlikely to fall into this category, unless the whole point of the legal document is to sow confusion, though that is a far from implausible account of at least some legal documents.

${ }^{28}$ Ronald DwORKin, TAKing Rights SERIOUSLy 134-36 (1977).

29 This account of concepts draws heavily on the epistemology of Ayn Rand, described most fully in AYN RAND, INTRODUCTION TO OBJECTIVIST EPISTEMOLOGY (1979), though it reflects my own understanding of the phenomenon and not necessarily the precise understanding of Rand or anyone else. There is an elaborate body of scholarship developing both this theory of concepts and the theory of perception on which the theory of concepts is grounded. See, e.g., HARRY Binswanger, How We KNOW: EPISTEMOlOGY ON AN OBJECTIVIST FOUNDATION (2014); CONCEPTS AND THEIR ROLE IN KNOWLEDGE: REFLECTIONS on ObJectivist EPISTEMology (Allan Gotthelf \& James G. Lennox eds., 2013); DAvid Kelley, The Evidence of the SEnSes: A ReAlist Theory of Perception (1986).

For another, seemingly different (though, in the end, I think complementary) application of this account of concepts to interpretation that, at first glance, appears to support Fleming in rejecting all forms of originalism, see TARA SMITH, JUdicial REVIEW IN AN OBJECTIVE LEGAL SYSTEM 151-62 (2015). Smith sometimes writes as though locating meaning in the intentions of communicators denies the objectivity of concepts as referring to real existents. See id. at 155. For reasons explained in the text to follow, I think that this misconstrues the cognitive and communicative function of concepts. Concepts are cognitive tools; they exist only in the minds of communicators. The meaning of a concept, in any given cognitive context, consists of real entities with real properties that are not limited to the thoughts of specific persons, see Allen Gotthelf, Ayn Rand's Theory of Concepts: Rethinking Abstraction and Essence, in CONCEPTS AND THEIR ROLE IN KNOWLEDGE: REFLECTIONS ON OBJECTIVIST EPISTEMOLOGY, supra, at 8-9, but the class of referents for any concept cannot be determined without appealing to a particular cognitive context. See RAND, supra, at 50. I believe (based on conversation with her) that Smith actually agrees with all of this, and I suspect that, in the end, she will oppose only some, but not all, forms of originalism as tools for the ascertainment of meaning. She may well, in all accounts, continue to oppose originalism as a theory of adjudication. Whatever her precise views on meaning are, Smith is clearly doubtful that legal authority can be grounded in the thoughts of specific individuals. See SMITH, supra, at 151 ("Textualism suffers from a constricted understanding of abstraction-of the objective meaning of words-and correspondingly (at least by implication), it attributes the ultimate authority of law to the beliefs of people. This results in a model of proper judicial review that renders the law subjective, rather than objective."). 
world-into mental entities that distinguish those units from other units in the knower's cognitive field and then serve as "file folders" to store information about those integrated aspects of reality. ${ }^{30}$ The meanings of concepts are the units themselves - the entities or relationships - to which the concepts refer, and concepts therefore presumptively include as part of their meaning aspects or attributes of those entities or relationships that have yet to be discovered or fully grasped. ${ }^{31}$ One can certainly have a concept that is limited to the particular entities or aspects of entities known or contemplated at a specific moment in time, and there may well be cognitive contexts in which that is an appropriate content for a concept, but that is not the usual, or presumptive, cognitive character of concepts. In order to determine whether a concept is limited to those specific instantiations-what Dworkin would call "conceptions" and what Fleming would call "expected applications"-one would have to look very carefully at the concept and the cognitive context in which it appears. In other words, it is an empirical question whether a particular concept is meant to function in its presumptive cognitive fashion by referring to a whole set of actual, known and unknown, entities or attributes of entities or to serve a more limited cognitive role by referring only to a specific subset of those entities or attributes. Thus, if an author refers to "the freedom of speech," it is possible that the author intends to refer only to some quite specific conceptions or instantiations of a potentially wider idea. But because that is not the standard cognitive role for concepts, one would expect to see some direct indication that the author so intends. Otherwise, the normal assumption would be that the author is referring to all past, present, and future instances of "the freedom of speech," including all of their known and unknown attributes.

This account of concepts seems to provide considerable support for the interpretative posture favored by Fleming, as it seems to counsel strongly against an "original expected applications" approach to interpretation. ${ }^{32}$ And, indeed, it does ... up to a point.

The crucial limiting consideration stems from how concepts serve a dual function as tools of both cognitive organization and communication. Because

On that I agree with her completely, but that has nothing to do with the actual content of communications. The Constitution means what it means regardless of whether or not it has any authority. I hope to further explore the extent to which my views and Smith's views are compatible in another work.

30 See Gotthelf, supra note 29, at 8-9; RAND, supra note 29, at 88 ("Since concepts represent a system of cognitive classification, a given concept serves (speaking metaphorically) as a file folder in which man's mind files his knowledge of the existents it subsumes. The content of such folders varies from individual to individual, according to the degree of his knowledge . . . but it pertains to the same referents, to the same kind of existents, and is subsumed under the same concept.").

31 See RAND, supra note 29 at 87 ("[A] concept is an 'open-end' classification which includes the yet-to-be-discovered characteristics of a given group of existents.").

32 See, e.g., FLEMING, supra note 1, at 22-23, 75-76. 
concepts group entities and relationships in order to allow minds to navigate a complex world, the way in which those groupings are made depends on the actions, and the cognitive needs, of a particular mind. ${ }^{33}$ One person in one setting may have, and need, a different way of organizing reality than a person in another setting. Of course, because reality is objective, and because human minds tend to have certain observable commonalities, there is likely to be considerable overlap in how different people, across both space and time, construct and apply concepts. But, as a matter of communication, if one is trying to understand authorial intentions, and therefore meaning, one needs to try to understand the particular way in which the specific author-in a particular time, place, and cognitive context-organized the world. The criteria that include or exclude entities from a concept are determined by the cognitive ordering of the author. Those criteria are what make the concept a concept. The concept, once formed, presumptively includes all known and unknown referents of the concept and all known and unknown attributes of the referents, but the criteria for determining the referents are fixed, for communicative purposes, by the cognitive context of the author. That is why originalism is, as Sai Prakash has put it, a "Default Rule" for interpretation. ${ }^{34}$ Concepts mean their referents, and what determines whether something is a referent is the intention of the communicator. Words represent concepts, concepts mean referents, and the classes of referents are determined by the cognitive ordering scheme of the mind that formed the concepts

To be sure, as we have already noted, an author who is trying to communicate effectively will try to grasp how a reader will understand his or her concepts. ${ }^{35}$ If the author is trying effectively to communicate information about some aspect of the world, he will try to use concepts that will effectively convey that information to the reader, which means that the reader's conceptual framework may actually, as a second-order matter, be intended to determine which features of the world the concept identifies. It is even likely that this reader-oriented approach is the default authorial intention in a very wide range of circumstances. If the difference between the author's and the reader's cognitive frameworks is small, this difference in perspective will not matter much. But the author may intend that, in the event of a conflict, the conceptual framework of a reader should determine the referents of a concept. One can even imagine communications where what looks like a concept is really just a blank placeholder to be filled in by future readers. It is an empirical question in any given case whether that was the author's intention.

33 See RAND, supra note 29, at 43 (explaining that "[a]ll conceptualization is a contextual process" and that "the content of [a person's] concepts is determined and dictated by the cognitive content of his mind").

${ }^{34}$ Saikrishna B. Prakash, Unoriginalism's Law Without Meaning, 15 Const. COMMENT. 529, 529-30, 541-42 (1998) (reviewing JaCK N. Rakove, Original MEANings: Politics AND IDEAS IN THE MAKING OF THE CONSTITUTION (1996)).

35 See Solum, supra note 12, at 1134. 
Hence, Dworkin and Fleming are right that interpretation-as-communication does not automatically, or even presumptively, entail resort to the particular conceptions or expected applications of authors - or, for that matter, of readers. Indeed, it presumptively entails precisely the opposite. But one must still determine what criteria for referents the author intended in the communication.

For example, in the context of the federal Constitution, what did the hypothetical, legally constructed author "We the People"-or, as an operational matter, the hypothetical, legally constructed reader targeted by the author-mean in 1791 by the term "liberty" in the Fifth Amendment's Due Process Clause? An empirical reader would not ask for a laundry list of specific human activities that exhaust the content of the concept. But an empirical reader would ask what criteria the author, and derivatively the public reader, had in mind for distinguishing things that fall into that author's/reader's concept of "liberty" from other things that are better organized-from the cognitive standpoint of the author/reader-under other conceptual headings. As a first-order matter, that inquiry does not involve moral theorizing and therefore does not call for the kind of "philosophic approach" favored by Fleming. It is an empirical inquiry. As a second-order matter, that inquiry might call for moral theorizing if the best empirical account of authorial intention is precisely that the concept of "liberty" in that context is meant to refer to those things that actually, under a best understanding, conform to a certain normative account of human action. There is nothing in empirical interpretation that a priori rules out this kind of second-order "moral reading," just as there is nothing in empirical interpretation that a priori requires it. One has to conduct an investigation into the facts to figure out how to establish the concept's referents.

As it happens, there is good reason to think that the concept of "liberty," as it would have been used by either an author or a reader of a legal document in 1791, would have been understood to have a relatively narrow set of referents, corresponding to freedom of bodily movement unrestricted by government agents. ${ }^{36}$ It would include all such movements, present and future, and thereby implicate all government restrictions on such movements, present and future (and therefore include movements and restrictions involving technology unimaginable to an eighteenth-century person), ${ }^{37}$ but an empirical account of authorial intention would not call for what Fleming would term a "moral reading," in which modern readers figure out the best normative account of "liberty." On the other hand, it is far less clear that one would necessarily reach

\footnotetext{
36 See, e.g., Obergefell v. Hodges, 135 S. Ct. 2584, 2632-33 (2015) (Thomas, J., dissenting) (finding that a historic reading makes it "hard to see how the 'liberty' protected by the [Fifth Amendment's Due Process] Clause could be interpreted to include anything broader than freedom from physical restraint").

37 See Gotthelf, supra note 29, at 15 (explaining that an "open-end" concept comprises "all relevantly similar instances, past, present, and future").
} 
the same conclusion when examining the term "liberty" as it appears in the Due Process Clause of the Fourteenth Amendment. ${ }^{38}$ Perhaps, when all is said and done, one would conclude that the terms have precisely the same referents, but that is an empirical question, on which I have no considered opinion.

Of course, an author or reader in the twenty-first century who writes or reads about "liberty" may well have a very different conceptual framework and may thus use the term "liberty" to describe a very different set of real-world phenomena. In interpreting a text, which conceptual framework determines its meaning? If interpretation means the discovery of communicative meaning, the answer is obviously the conceptual framework intended by the communicating author. If interpretation means something else, such as figuring out which set of referents for the concept of "liberty" will lead to the best consequences, it is quite possible that neither the author's nor the (current) reader's framework is optimal.

The one-run-on-sentence-while-metaphorically-standing-on-one-foot ${ }^{39}$ version of this analysis, for whatever it is worth, is: As a matter of communication, authorial intentions determine the criteria for referents for concepts, though those intentions, especially with regard to legal documents aimed at third persons, often get operationalized in practice as the intentions of a hypothetical reader, and that hypothetical reader's cognitive framework thus determines the criteria for inclusion of units (things and relations) within the concepts used in the communication, though the concepts themselves presumptively include all known and unknown attributes of the units to which the concepts refer, so that people like Fleming and Dworkin are right that interpretation-as-communication does not automatically, or even presumptively, entail resort to the particular conceptions or expected applications of either authors or readers, but it does-to return to the beginning-entail resort to the criteria for determining the referents of the concepts employed by the hypothetical reader, and that is, by its nature, an originalist enterprise.

So, in the end, Fleming is right that constitutional interpretation, and interpretation of any communicative act, requires what one might call a "philosophic approach." But I think he has the wrong branch of philosophy in mind. The branch of philosophy that is required for sound interpretation is epistemology, not moral theory, with a strong dose of philosophy of language

${ }^{38}$ Ryan C. Williams, The One and Only Substantive Due Process Clause, 120 YALE L.J. 408, 415-17 (2010) (arguing that the Fourteenth Amendment's Due Process Clause incorporates "a recognizable form of substantive due process" that the Fifth Amendment's Due Process Clause lacks).

${ }^{39}$ In the course of delivering a version of this comment as oral remarks, it was conclusively demonstrated that my motor-planning difficulties and general all-around klutziness do not allow me to stand on one foot long enough to speak this sentence. Not even close, actually. 
lurking in the background. The research agenda for a sound originalism must focus on these questions of meaning, language, and communication.

Of course, for many people, originalism is not, or not only, a theory of interpretation, but is also a theory of adjudication. ${ }^{40} \mathrm{It}$ is, for some people, a prescription for how real-world actors should decide actual cases with tangible consequences. ${ }^{41}$ To translate interpretative meaning into a theory of adjudication does require moral philosophy, as Fleming suggests. Once you know what the Constitution means, it is a question of moral and political theory, not of interpretative theory, what to do with that meaning. Should that meaning guide conduct in any way-more than, for example, the Bible, Atlas Shrugged, The Communist Manifesto, the political platform of the liberal wing of the Democratic Party, or the menu at IHOP? Interpretative theory has nothing to say about that question. Originalism, in the form of empirical reading, is not a prescription for anything. It is a means of acquiring facts.

\section{What Is Old About THE Old ORIGINALISM AND NEW About THE NEW ORIGINALISM (AND NEW NEW ABOUT THE NEW NEW ORIGINALISM)?}

Old originalists, such as Raoul Berger and Robert Bork (at least before $1990^{42}$ ), did not talk as I do. They did not discuss epistemology, concepts, communication, and the philosophy of language. They discussed such things as judges, democracy, constraint, and authority. That is because Fleming is right about yet another thing: the old originalism was an "ism."43 It was not actually a theory of interpretation or meaning, but was rather a theory of adjudication or decision-making. As such, it belongs in the domain of moral or political theory rather than interpretative or legal theory. Put more bluntly: the old originalists were moral readers. They employed abstract commitments to certain conceptions of democracy, judicial role, and the rule of law rather than employing abstract commitments to left-liberalism as "interpretative" tools, but, as the old joke goes, that is just haggling over the price.

That is less true of the "new originalism"-though, as I will shortly explain, it may more largely be true of the "new new originalism." The new originalism is the product of a generation of theorists, many of whom were students of Robert Bork or Antonin Scalia, who began recasting originalism in the mid-

40 See generally Gary Lawson, Originalism Without Obligation, 93 B.U. L. REv. 1309 (2013) (distinguishing between originalist theories of interpretation and originalist theories of adjudication).

${ }^{41}$ See id. at 1313.

42 Judge Bork's views shifted somewhat while he was writing The Tempting of America because (1) he had the good sense to employ Steve Calabresi as his research assistant, and (2) he had the intellectual integrity to listen to his research assistant and to change even some long-held positions in response to persuasive argument. He did not make it all the way to an empirical reading of the Constitution, but he traveled quite a distance, and that journey deserves acknowledgment.

${ }^{43}$ FLEMING, supra note 1, at 3. 
1980s and early 1990s. Important figures in that movement include (and I apologize to everyone that is missing from this list) Randy Barnett, Steve Calabresi, John Harrison, John McGinnis, Mike Paulsen, Sai Prakash, Mike Rappaport, and myself. The movement is sometimes cast as a shift in focus from original authorial intentions to original public meaning, largely because of a speech given in 1986 by then-Judge Scalia that highlighted the distinction between those two ideas. ${ }^{44}$ That shift, which takes many forms (including the form, defended here, which grounds itself in authorial intentions but operationalizes those intentions as public meaning in the specific context of a legal document "authored" by a hypothetical "We the People") is an important part of the picture, but it misses the key development. The real move reflected in the new originalism was from originalism as a theory of adjudication and governance to originalism as a theory of interpretation and meaning. To be sure, virtually all of the new originalists (essentially everyone except me) put forth originalism both as a theory of interpretation and as a theory of governance, but new originalists generally acknowledge that those are distinct moves that require distinct lines of reasoning to defend. Thus, I think Fleming gets it precisely backwards when he characterizes the new originalism as a move from anti-Warren Court tirades to a governing judicial philosophy ${ }^{45} \mathrm{He}$ has taken bad guidance from Keith Whittington, who postulated-with absolutely zero evidence that I can see-precisely such a move as the explanation for the emergence of the new originalism in the Reagan and postReagan years. ${ }^{46}$ That is the sort of thing that sounds nice to political scientists who like that kind of explanation. It just happens to be, I believe, wildly false, and indeed backwards, as an account of the emergence of the new originalism. The new originalists, most of whom I personally have known at least casually since the 1980s, were engaged in an intellectual rather than a political enterprise. That may disappoint political scientists (and it may seem incredible to people for whom everything is political and who cannot even imagine separating politics from ideas), but that was certainly my understanding of the movement as I watched it develop.

Fleming's attribution of "ism-ism," however, may well be right about at least some portion of the so-called "new new originalism," 47 which began emerging in the late 1990s and has seen considerable flowering in the twenty-

\footnotetext{
44 Justice Antonin Scalia, Address Before the Attorney General's Conference on Economic Liberties in Washington, D.C. (June 14, 1986), in OfFICE OF LeGAL POLICY, U.S. DeP'T of Justice, Original Meaning Jurisprudence: A SourcebooK 106 (1987) (explaining that he "ought to campaign to change the label from the Doctrine of Original Intent to the Doctrine of Original Meaning").

45 See FLEMING, supra note 1 , at 5.

46 See Keith E. Whittington, The New Originalism, 2 GeO. J.L. \& Pub. Pol'y 599, 60304 (2004).

47 Peter J. Smith, How Different Are Originalism and Non-Originalism?, 62 HaSTINGS L.J. 707, 709 (2011).
} 
first century. Just as originalism describes a family of theories rather than a single approach, the new new originalism covers a wide spectrum..$^{48}$ If there is a defining feature of the new new originalism, it is perhaps its focus on the distinction between interpretation, or the ascertainment of meaning, and construction, or the implementation and supplementation of that meaning in the course of adjudication. ${ }^{49}$ Fleming is, I believe, right that what new new originalists call "construction" could just as easily be called "moral reading" because it involves filling in space with something other than empirical reading..$^{50}$ Once one goes beyond meaning, just about anything that fills the gap will fit Fleming's definition of a moral reading. All that changes is the set of abstract commitments that one uses in place of meaning.

Even Justice Scalia, who is something of a focal point for all three generations of originalism because he made important contributions to each, was a moral reader (I did say that comparing moral reading and empirical reading would reveal some strange bedfellows). Justice Scalia had a much more sophisticated and nuanced understanding of interpretative theory than did, for example, Raoul Berger, but Justice Scalia was also in the grip of a theory of normative legitimation. He shaded his readings of the Constitution to fit a particular conception of (1) normatively binding law and (2) institutional judicial role. As he said in print, "I take the need for theoretical legitimacy seriously, and even if one assumes ... that the Constitution was originally meant to expound evolving rather than permanent values, ... I see no basis for believing that supervision of the evolution would have been committed to the courts." 51 In this general understanding of the relationship between interpretation and normative theory, he is firmly aligned with Jack Balkin, who speaks for virtually everyone (except me) in the American legal community when he writes that "[c]oncerns about legitimacy underwrite theories of constitutional interpretation ... [and] we argue for or against different theories of constitutional interpretation in terms of their effects on legitimacy." 52

Are Justice Scalia and Jack Balkin - and, for good measure, Flemingwrong to think this way? Not necessarily; it depends entirely on what they are trying to do. If one is trying to prescribe normative guidance and establish legitimacy, normative theory is the right place to look (though I suspect that none of Justice Scalia, Balkin, or Fleming would very much like the answers that an objectively sound normative theory would actually provide). But if one is trying to ascertain meaning, then not so much. The Constitution means what it means, whether or not that meaning makes it normatively attractive or

\footnotetext{
${ }^{48}$ For a good introduction, see the various essays in Symposium, The New Originalism in Constitutional Law, 82 FORDHAM L. ReV. 371 (2013).

49 See Gary Lawson, Classical Liberal Constitution or Classical Liberal Construction?, 8 N.Y.U. J.L. \& LIBERTY 808, 814-16 (2014).

50 See FLEMING, supra note 1, at 37-38.

51 Antonin Scalia, Originalism: The Lesser Evil, 57 U. CIn. L. Rev. 849, 862 (1989).

52 JACK M. BALKIN, LIVING ORIGINALISM 64 (2011).
} 
unattractive and legitimate or illegitimate, and whether or not a proper conception of the judicial role requires, allows, or forbids judicial application of it. Meaning is an empirical fact.

Empirical reading is not an "ism." It is simply the application of basic principles of epistemology to one particular search for knowledge. Empirical readers qua empirical readers have no interest in democracy, constraint, or authority (though they might have interest in such subjects in capacities other than as empirical readers). They are looking for the communicative content of human utterances and, in particular, of utterances that were made at specific points in space and time by joint authors who cast their works as the products of a hypothetical, legally constructed entity called "We the People." A good empirical reader might well be a full-fledged anarchist who sees no plausible argument for political authority, constitutional or otherwise, considers a search for legitimacy a fool's errand, and regards democracy as a large-scale mugging that takes place in polling booths rather than alleys. ${ }^{53}$ Such a person, again qua empirical reader, has as little in common with old-style originalism as he does with Fleming's moral reading.

I doubt whether Fleming's project is aptly characterized as developing a moral reading of the Constitution. Fleming is really proposing a moral application of the Constitution (from the perspective of a fundamentally flawed moral theory, but that is a story for another day and another life). Reading the Constitution and applying the Constitution are two distinct enterprises that require very different tools and skills.

To illustrate how Fleming's project is about application rather than interpretation, consider his account of the "three incorrigible flaws" 54 that he sees in the old originalism:

(1) [t]he moral burden of the old originalism with regard to both rights and powers -its concrete intentionalism entails that Brown v. Board of Education was wrongly decided and that most of the modern federal government is unconstitutional; (2) the authoritarianism of the old originalism is a massive insult to the dignity of both the founders and us - it attributes arrogance to the authors of the norms of the Constitution

${ }^{3}$ See Gary Lawson, No History, No Certainty, No Legitimacy . . . No Problem: Originalism and the Limits of Legal Theory, 64 FLA. L. REV. 1551, 1567 n.51 (2012) ("Indeed, in my nonprofessional life, I am very concerned about political legitimacyespecially since, as a libertarian anarchist, I do not find much of it anywhere. I certainly do not find it in democracy. If two people come upon a third in an alley and vote to take the third person's wallet, there is nothing legitimate about the action (unless, of course, they have a valid claim to the wallet based on something other than their vote, such as prior theft of the wallet by the third person). If one multiplies the numbers on each side by $100,000,000$ and changes the alley to a series of polling booths, all one has changed is the number of victims and the number of perpetrators. Democracy is a fine way for a group to decide where to have dinner or who will chair the next faculty meeting. It is not a fine way to decide who gets to spend my money or which substances I can ingest.").

${ }^{54}$ FLEMING, supra note 1, at 4. 
and subservience to the subjects of those norms (to add further insult, its proponents serve it up to us in the name of democracy); and (3) its concrete intentionalism is untenable as a theory of interpretation of our Constitution, which establishes a charter of abstract aspirational principles and ends and an outline of general powers, not a code of detailed rules. ${ }^{55}$

Rather obviously, the first two criticisms, entirely apart from whether they are accurate ${ }^{56}$ are solely concerned with normative political theory and have nothing to do with interpretation as such. They do not even present themselves as flaws in reading the Constitution, in the sense of discerning the communicative signals contained therein. These criticisms address only the consequences of treating an originalist reading as a guide to action in the real world. This says nothing, even in principle, about whether the reading is correct as a reading. The third criticism at least takes the form of an argument about interpretation and meaning, but it too is driven, I believe, by normative concerns about legitimacy, goodness, and such. It is very difficult to read the Constitution-literally to sit down and read the Constitution from start to finish-and conclude that it is a charter of abstract commitments rather than a set of detailed rules. It is full of detailed rules. There are seemingly endless, tedious, soporific paragraphs laying out detailed rules. Then, on some occasions, there are a few provisions that seem to stretch more broadly and could plausibly be seen as aspirational in character. It is semantically possible to jump on those few provisions and transform them into the centerpiece of interpretation. It is not pragmatically possible to do that by reading the Constitution for what it is. One has to be reading the Constitution through a normative lens to get there.

And, indeed, Fleming casts his entire lifelong project as an exercise in perfecting the Constitution. As he eloquently puts it: "A moral reading, because it understands that the quest for fidelity in interpreting our imperfect Constitution exhorts us to interpret it so as to make it the best it can be, offers

\footnotetext{
$55 I d$. (footnotes omitted).

${ }^{56}$ Most of the modern federal government is obviously unconstitutional under any plausible originalist account, be it old or new. Whether that is a moral burden or a moral virtue depends on what foundationally sound moral theory prescribes about the modern federal government. Whether Brown was rightly or wrongly decided, at least from the standpoint of empirical reading, depends on whether public education is a "privilege or immunity" and, if so, whether separate-but-equal facilities "abridge" that privilege or immunity; I have never researched those questions, but really smart people who have done so seem to think that the answer to both questions is yes, and that is the sort of thing about which they are likely to be right. See Steven G. Calabresi \& Michael W. Perl, Originalism and Brown v. Board of Education, 2014 MiCH. ST. L. REv. 429, 434-35. Old originalists will have to answer the relevant questions for themselves. As to whether authoritarianism of the sort described by Fleming is a bad idea: it depends on whether the authorities are more likely to get right answers than modern folk. Looking around at the world, I am inclined to think that the old folks were, if not smarter, then at least wiser than modern public figures.
} 
hope that the Constitution may deserve our fidelity, or at least may be able to earn it." ${ }^{7}$ An empirical reader, or indeed any kind of reader rather than applier, would not try to make the Constitution the best that it can be, or even moderately tolerable, when performing the exercise of discerning communicative signals. He or she would read the Constitution for what it is..$^{58}$ Once that communicative content is known, one can then make judgments about its merit, and therefore can make judgments about the extent to which one is prepared to take it as real-world guidance. Such judgments must, from the standpoint of ascertainment of meaning, follow rather than precede the act of interpretation. Otherwise, it is not actually a reading of the Constitution; it is a construction of the Constitution. ${ }^{59}$ Perhaps the real subtitle of this book should be For Moral Constructions and Against Originalisms. Because a good percentage of originalist theorizing these days is actually construction rather than interpretation, which means normative prescription rather than reading, that would be a fine and productive opposition.

The not-very-startling upshot, which is neither threatening nor even especially troubling to Fleming's project, is that Fleming is not much interested in the ascertainment of meaning. He is interested in providing guidance for real-world judgment. He wants to tell judges and other officials how to decide cases - which really means telling judges and other officials who to shoot, whose lives to control, and whose wealth to seize. That is, of course, what pretty much everybody in the world of constitutional interpretation except me is trying to do, and the conflicts among the contending theorists reduce to who gets shot, whose lives get controlled, and whose wealth gets seized. The actual empirical meaning of the Constitution sometimes plays a role in that process, but mostly not. And that is true across the board. To the extent that Fleming is concerned with describing constitutional practice rather than ascertaining constitutional meaning, it is very hard to argue that he has it wrong. ${ }^{60}$

57 FLEMING, supra note 1, at 20 (footnote omitted).

58 See SMiTH, supra note 25, at 237, 264-65.

${ }^{59}$ Lawrence B. Solum, Communicative Content and Legal Content, 89 Notre DAME L. REv. 479, 483 (2013) (defining construction as "the determination of the legal content and legal effect produced by the legal text").

${ }^{60}$ During the oral exchange on which this Comment is based, Sandy Levinson suggested that there are large chunks of the constitutional world in which the actual meaning of the text controls actions-and does so with such thoroughness that it is simply taken for granted. Rhode Island gets two votes in the Senate, and the President gets to veto legislation, and while some people grouse about what a bad idea those things might be, no one doubts that they are part of the Constitution's meaning. See U.S. ConST. art. I, § 3, cl. 1 ("The Senate of the United States shall be composed of two Senators from each State, chosen by the Legislature thereof, for six Years; and each Senator shall have one Vote."); id. art. I, § 7, cl. 2 ("Every Bill which shall have passed the House of Representatives and the Senate, shall, before it become a law, be presented to the President of the United States: If he approve he shall sign it, but if not he shall return it, with his Objections to that House in 


\section{REALITY BITES}

Fleming deeply dislikes interpretative theories that are "authoritarian," in the sense that they prescribe answers for present readers rather than give readers a framework for reaching their own answers. Put aside whether it is a good or bad thing for a theory to be authoritarian in that sense (surely the answer depends, at least to some degree, on whether the authority is more likely than the subjects to get the right answers). ${ }^{61}$ Is empirical reading authoritarian?

It clearly is not authoritarian-nor libertarian-in the sense meant by Fleming, because empirical reading prescribes no particular course of action. It does not tell anyone what to do with the meaning of the Constitution once they have it. It does not instruct decision-makers to follow that constitutional meaning rather than their own best judgments about moral theory if the two seem in conflict. Originalism as an "ism" is certainly authoritarian; indeed, it wears that label proudly as a badge of honor. But empirical reading stays out of that arena altogether.

There is one respect, however, in which empirical reading is authoritarian. For empirical readers, meaning is fixed (at least presumptively) by the cognitive frameworks of historically situated authors - real or hypotheticalthat determine the criteria for referents for the concepts used in communication. Those frameworks are facts. The discernment of meaning is an archaeological rather than creative task. But that is authoritarian in the same way that, for example, geology is authoritarian. The facts are what they are, and the facts dictate the inquiry.

which it shall have originated, who shall enter the Objections at large on their Journal, and proceed to reconsider it. If after such Reconsideration two thirds of that House shall agree to pass the Bill, it shall be sent, together with the Objections, to the other House, by which it shall likewise be reconsidered, and if approved by two thirds of that House, it shall become a Law.”). All true. But sometimes not true. The Recess Appointments Clause is about as clear as it could be that recess appointments are permissible only when a vacancy occurs when the Senate is in recess-meaning its between-sessions recess rather than a break within a session. See Robert G. Natelson, The Origins and Meaning of "Vacancies that May Happen During the Recess" in the Constitution's Recess Appointments Clause, 37 HARV. J.L. \& PUB. POL'Y 199, 213-27 (2014); Michael B. Rappaport, The Original Meaning of the Recess Appointments Clause, 52 UCLA L. REV. 1487, 1491 (2005). But if that gets too inconvenient for the ambitions of the political class (ambitions that regularly cross party lines), too bad for the clear meaning of the Constitution-and the Supreme Court can usually be counted on to go with the practice rather than with the Constitution. See NLRB v. Noel Canning, 134 S. Ct. 2550, 2573 (2014). For an even more dramatic departure from the unmistakably clear meaning of a hard-wired structural provision, check out Tashjian $v$. Republican Party of Connecticut, 479 U.S. 208, 225-29 (1986), and prepare to be astounded. Does anyone seriously think that if today's social justice warriors get control of the Supreme Court, they will let something like the text of the Senate Clause stand in the way of their agenda?

61 See supra note 56. 
From the standpoint of empirical readers, Joe Friday would have been a great interpreter. 